\section{En app i enkleste laget}

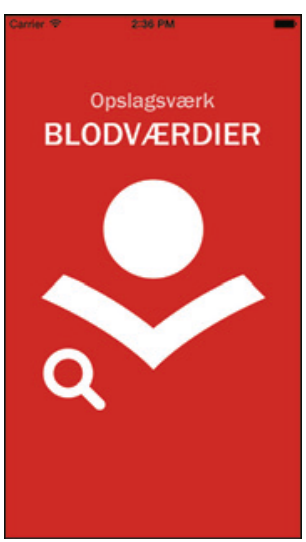

Peter Fahmy, Troels Bygum Knudsen Blodværdier - app

192 s. København: Munksgaard, 2014. Pris DKK 45

ISBN 978-87-628-1166-9 (iPhone app)

Appen Blodvcerdier inneholder et alfabetisk oppslagsverk over de vanligste blodprøvene som rekvireres i klinisk praksis. Målgruppen er sykepleiere, medisinstudenter, bioingeniører og annet helsepersonell som «trenger informasjon om blodprøver her og nå». Appen er basert på den danske læreboken Blodvcerdier, skrevet av Peter Fahmy og Troels Bygum Knudsen ved Hvidovre sykehus.

Designet er enkelt, og appen inneholder få funksjoner. Den er således svært enkel å bruke. Man kan velge mellom alfabetisk oppslag i venstre kolonne eller å taste inn søkeord direkte i høyre kolonne. For hver enkelt prøve finner man så informasjon om indikasjoner, bakgrunn og tolking av unormale verdier. Tekstene er kortfattede og oversiktlige, og inneholder i varierende grad supplerende klinisk informasjon. For noen prøver oppgis også referanseområde.

Selve søkefunksjonen er begrenset til navnet på de ulike blodprøvene, det er ikke lagt inn noen emneknagger. Det vi si at søk som for eksempel «diabetes» og «nyrefunksjon» ikke gir noen treff. Appen gir på ingen måte en komplett oversikt over alle blodprøver. Den inneholder ingen mikrobiologiske prøver, heller ikke medikamentspeil.

Boken som appen er basert på, inneholder ifølge omtalen «flere praktiske opplysninger og beskrivelser av utvalgte organprøver og prøvesamlinger». Jeg tror appens lærings- og nytteverdi hadde vært større om man hadde valgt å legge til mer av denne typen informasjon. Appen kan kanskje være et nyttig supplement for medisinstudenter tidlig i studiet, og for helsepersonell som i mindre grad har behov for kunnskap om laboratorieprøver - som også er den beskrevne målgruppen. For andre vil jeg tro at konkurrerende, og mer detaljerte, oppslagsverk, som den norske appen Blodprøver, av Sigve Dhondup Holmen, eller den gode gamle «blåboka» til Fürst Medisinsk Laboratorium (som foreløpig ikke finnes som app, men er tilgjengelig på nett) vil være et bedre valg.

\section{Benedicte Rønning}

Turnuslege, Sagene lokalmedisinske senter Oslo

\section{Uutnyttet potensial i app-form}

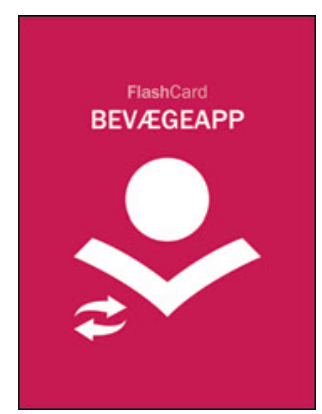

\section{Helena Bollerup \\ Bevægeapp}

App med ca. 200 spørsmål og svar.

København: Munksgaard, 2014. Pris NOK 42

ISBN 978-87-628-1359-5 (iPhone app)

«Bevægeapp er med brugervenligt design et sjovt og nyttigt værktøj for medicin- og fysioterapistuderende ved indlæring og repitition av bevægeapparatets anatomi» heter det $\mathrm{i}$ beskrivelsen i App-store. I strid med hva man kan forvente ut fra tittelen, og i lys av hva man er blitt vant med av fancy apper til sin daglige følgesvenn, består denne utelukkende av spørsmål og svar, blottet for audiovisuelle distraksjoner. I hvilken grad designet, i firkantet rødt og blått, er spesielt «sjovt», får den enkelte bedømme, men det er enkelt og oversiktlig, og lar dermed brukeren holde fokuset på faget.

Appen består altså av ca. 200 spørsmål og svar. En stor del, om ikke de fleste, av disse spørsmålene ville jeg heller kalt utgreiingsoppgaver, og de er tidvis så vide at man kan ha problemer med å skjønne hva de er ute etter i svaret. Eksempler på spørsmål er «Beskriv brystkassen som helhed», «Beskriv kneleddet mht navn, type og artikulerende flater», «Benævn udspring, insertion og innervation for $\mathrm{m}$. coracobrachialis, samt hvilken funktion denne muskelen har». Her vil man igjen ut fra lovnaden om «sjov» kanskje forvente seg en noe mer kontant quiz-stil, «Trivial Pursuit» eller «Kvitt eller dobbelt», og således bli skuffet. Når det er sagt, er svarene på kortene grundige og utfyllende, og appen kan slik brukes som kunnskapskilde i seg selv (da fortrinnsvis i kombinasjon med et anatomiatlas).

Det er i enkelte svar også tatt med kliniske eksempler og huskeregler. Dette er positivt og motiverende for læring. Jeg stusser dog over at man har valgt å ta med dette for lesjon i nervus thoracicus longus, og ikke i nervus medianus.

Brukerflaten er i likhet med designet, svært enkel. Man kan velge å ta for seg de ulike kroppsdelene hver for seg, eller trekke tilfeldige kort. Menyen er stort sett oversiktlig og grei, selv om noen underemner er inkonsekvent plassert. Når det gjelder svarkortene, er disse, som sagt, grundige og utfyllende, men jeg vil si man har en del å hente på system i fremstilling og layout - det er helt ensfarget tekst $i$ én størrelse og noe rotete bruk av punkter og overskrifter.

På tross av et noe halvferdig preg synes jeg alt i alt den fungerer godt som et verktøy for repetisjon av anatomi. Er du tilhenger av å bruke din digitale duppeditt i studieøyemed, er det kanskje verdt å bruke 42 kroner på denne appen. Forvent dog ikke så mye «sjov». 